\title{
Sediment Dynamics and Rating Curve Development on River Osun, South-Western Nigeria
}

\author{
Olaniyan, O.S., Adegbola, A.A., Oladeji, O.S, Olaoye, R.A. \& Ayanniyi, T.J. \\ Department of Civil Engineering, \\ Ladoke Akintola University of Technology \\ Ogbomoso, P.M.B 4000, Oyo State, Nigeria \\ Emails: osolaniyan@lautech.edu.ng, tj4rose@yahoo.com
}

\begin{abstract}
Sediment transport rate hinge upon hydraulic flow, upstream sediment supply and bed composition. There is paucity of Information on sediment dynamics on River Osun. Landsat7 Imageries from African Regional Center for Space Science and Technology Engineering - Education (ARCSSTE-E), Obafemi Awolowo University, Ile-Ife, Osun State was used to produce land use map of the study area. The acquired image was layer stacked and sub setted using the study area boundary. The sub settted image was classified using maximum likelihood algorithm of supervised classified technique. Thereafter, the classified image was exported as raster layer to ArcGis 10.3 environment where the coordinate of the study area were overlaid on the exported land use classification. Stage and discharge were measured across River Osun was measured from July 2015- June, 2016. Rating equation was developed using stage and discharge records and was validated using three months stage -discharge record from March 2017 to May, 2017. The agricultural activities observed from the land use map are responsible for the highest suspended sediment concentration at the upstream while the urbanization contributes to the highest discharge recorded at the mid-stream. The discharge and cross sectional area across River Osun ranges between $(0.53-17.46) \mathrm{m}^{3} / \mathrm{s}$ and $(3.83-47.46) \mathrm{m}^{2}$. The corresponding slope and depth ranged from $(0.0032-0.0046)$ and $(0.2-1.9) \mathrm{m}$, respectively. The flow area across the river in dry and wet season ranges between $3.83-19.2 \mathrm{~m}^{2}$ and $13.5-47.5 \mathrm{~m}^{2}$, respectively. The developed rating equation on River Osun was $\mathrm{Q}=0.467(\mathrm{G}-0.368)^{749}$ with $78 \%$ coefficient of regression between simulated and measured discharge values.

Keyword: Sediment Dynamics, Rating Curve, Development, River Osun \& South-Western Nigeria
\end{abstract}

Aims Research Journal Reference Format:

Olaniyan, O.S., Adegbola, A.A., Oladeji, O.S, Olaoye, R.A. \& Ayanniyi, T.J. (2018): Sediment Dynamics and Rating Curve Development On River Osun, South-Western Nigeria. Advances in Multidisciplinary Research Journal. Vol. 4. No. 2, Pp 63-72

\section{INTRODUCTION}

River Osun is the largest river in Osun State, the major tributaries of this river include Erinle River, Oba River and Omi Osun River. It was gauged where the tributaries were impounded for reservoir. For a scientific approach to different river problems, proper planning and design of water resources project, an understanding of the morphology and behavior of the river is a prerequisite. Morphology (of river) is an aspect of science that has to do with the change of river plan form and cross section due to sedimentation and erosion. In the field, dynamics of flow and sediment transport are the principal element. The morphological studies therefore play a crucial role in planning, designing and maintaining river engineering structure. There has been a growing awareness about the need for making up morphological study of river in the country, especially with particular reference to their unique problems (Adegbola and Olaniyan, 2013). Flood is the major natural disaster in Nigeria, Many lives and properties have been lost as a result of poor water management. The study of water behavior is very important in forecasting of future flooding occurrence. Sediment transport plays a vital role in water behavior. Hence, the study of sediment transport becomes important in reducing the menace of flood in Nigeria. Water supply is a basic requirement of life and it is important to sustain life. 
The availability of quality water is one of the most important factors that determine our health. Therefore any study that is related to sustenance of human life is worthwhile.

\section{METHODOLOGY}

The data was collated on the river and it includes: discharge $(Q)$, water-surface width $(B)$, flow depth $\left(Y_{0}\right)$, water-surface slope (So).

\subsection{Brief Description of the Study Area}

River Osun is a river that flows southwards through Central Yoruba land in Southwestern Nigeria into the Lagos lagoon and the Atlantic Gulf of Guinea. The origin of River Osun is at Ekiti State $\left(8^{\circ} 20^{\prime} \mathrm{N} 5^{0} 16^{\prime} \mathrm{E}\right)$ while its mouth is at Lekki lagoon $\left(6.563210^{\circ} \mathrm{N} 4.062032^{\circ} \mathrm{E}\right)$. It is one of the several rivers ascribed in local mythology to have a woman who turned into flowing water after some traumatic event frightened or angered her. Figure 1 shows the map of River Osun.

The river channel was divided into sub channels and the cross sectional geometrical variables such as area, wetted perimeter, channels top width were computed for each sub channel. The expressions were used to calculate the cross section in line with (Olaniyan, 2014).

$$
\begin{aligned}
& A_{i}=0.5\left(y_{i}+y_{i}+i\right) d x i \\
& A_{i}=\sum_{i=1}^{m} A_{i} \\
& p_{i}=\left(d x_{1}^{2}+\left(y_{i}-y_{i}\right)^{2}\right)^{1 / d_{2}} \\
& T=\sum_{i}^{N}=1 \pi_{i}
\end{aligned}
$$

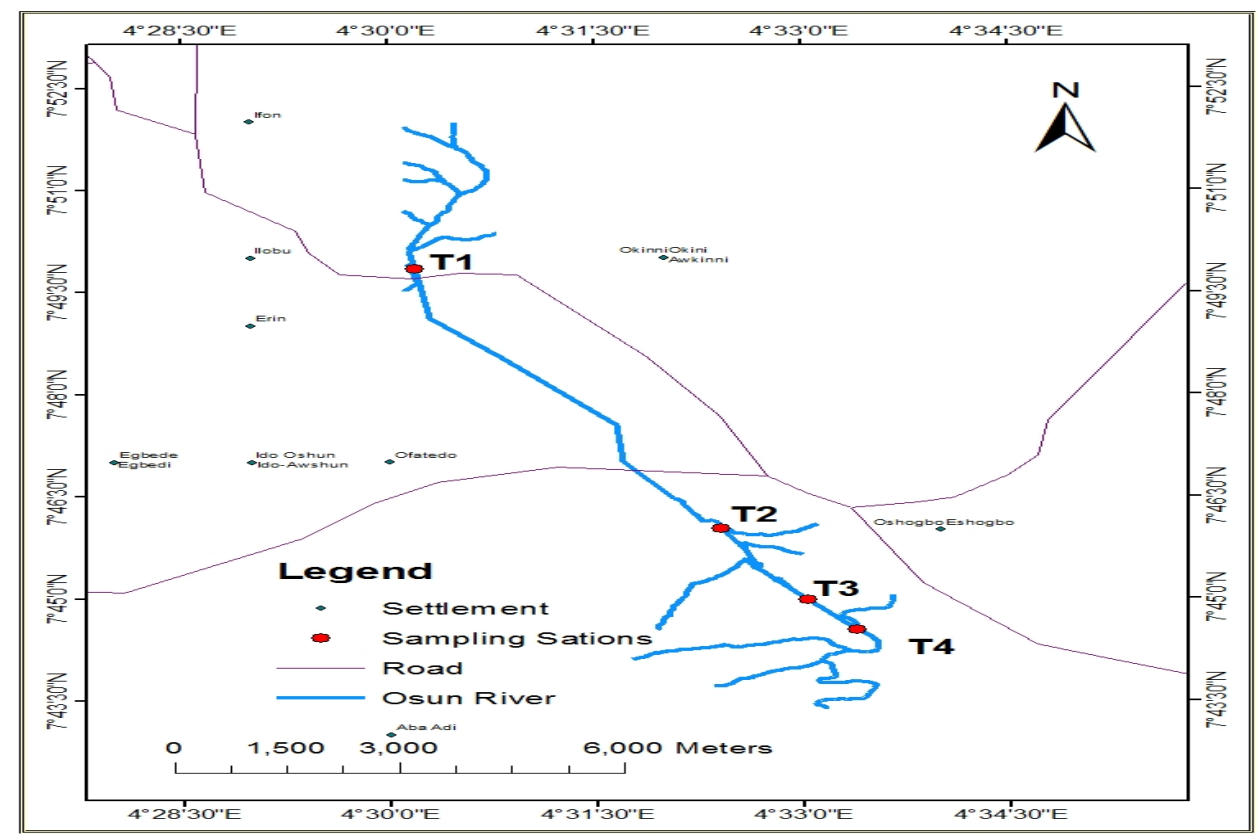

Figure 1: Map of the Study Area showing the Sampling Stations 
Where:

$\mathrm{Ai}$, and $\mathrm{Pi},=$ area and wetted perimeter of a subsection

$\mathrm{Ti}=$ top width of a sub-channel

$\mathrm{A}_{\mathrm{i}}, \mathrm{P}_{\mathrm{i}}$, and $\mathrm{T}=$ Area, wetted perimeter and top width of the whole cross section, respectively:

$\mathrm{m}=$ number of subsections

$\mathrm{N}=$ number of computed sub-channels

Flow Area is the gross section of the river channel at the sampling point. Producing a cross section of a river channel is a basic river field work skill. Equipment used for this task (i) A rigid calibrated rope, (ii) Surveying pole for taking actual depth readily, (iii) A long waterproof tape for measuring the width of the river.

The width of the river was obtained by stretching a tape from one bank the other bank at $90^{\circ}$ to the course of the river, the starting and finishing points for the measurement are the points at which the dry bank meets the water. In order to avoid drag induced by the tape making contact with the flowing water, and the consequent possible increase in distance to be measured due to the likely scotching of tape into a curve, it has to be stretched at about $20 \mathrm{~cm}$ above water level. The ends of the section to be measured will be determined by observation from directly above the tape at $90^{\circ}$ of the ground. Observation from directly above the tape is to ensure that the error is minimal (Olaniyan, 2014). The readings were taken at an interval of 4 meters. The tape was stretched from one bank to the other is to serve as a guide-to ensure that you take measurements in a straight line. It is also a convenient way of measuring the intervals between readings.

A calibrated rope was immersed in the water every $4 \mathrm{~m}$, until the concrete cube weight end touches the bed of the river. The depth measurements from the stream were recorded. The measured depths and distance were used to draw a chart of the stream shape. In other to examine the effect of human activities on River Osun, lands at 7 was acquired from global land use and land cover facility achier. The acquired image was layer stacked and sub setted using the study area boundary. The sub setted image was classified using maximum likelihood algorithm of supervised classified technique. Thereafter, the classified image was exported as raster layer to ArcGis 10.3 environment where the coordinate of the study area were overlaid on the exported land use classification.

\subsection{Rating Curve Development}

Stage and discharge were measured across River Osun was measured from July 2015- June, 2016. Rating equation was developed using stage and discharge records and was validated using three months stage -discharge record from March 2017 to May, 2017. This rating equation developed was used to estimate discharge from February 2016 to June 2016 to complete the seasonal discharge data on River Osun.

Running method was used to develop the rating equation in-line with (Adegbola and Olaniyan, 2013). Three points A, B and C on the curve was selected such that their discharges are in geometrical progression i.e.

$\frac{Q A}{Q D}=\frac{Q B}{Q^{\circ}}$

This method assumed that the lower part of the stage-discharge curve is a parabola. The constant (a) can be estimated using equation:

$$
a=\frac{G_{1} C_{3}-G_{2}^{2}}{\left(G_{1}+G_{3}\right)-2 G_{2}}
$$


From Gauge-Discharge equation,

$$
Q=G_{Y}(G-a)^{\beta}
$$

$\log Q=\beta \log (G-a)+\log C r$

$Y=\beta X+b$

Using equation 3.7(a) and 3.7(b) for the data, the unknown variables $(\beta, b$ and $r)$ can be determined by:

$$
\begin{array}{ll}
\beta & =\frac{N(\varepsilon X Y)-(\varepsilon X)(\varepsilon Y)}{N\left(\varepsilon X^{2}\right)-(\varepsilon X)^{2}} \\
b=\frac{\varepsilon V-\beta(\varepsilon X)}{N}=\log C_{Y} & 7(\mathrm{c}) \\
r=\frac{N(\varepsilon X Y)-(\varepsilon X)(\varepsilon Y)}{\left(\sqrt{N\left(\varepsilon X^{2}\right)}-(\varepsilon X)\right)^{2}\left(\sqrt{N\left(\varepsilon Y^{2}\right)}\right)-\left(\varepsilon Y^{2}\right)} & 7(\mathrm{e})
\end{array}
$$

Note that $r=\log Q, X=\log (G-a)$

\section{RESULTS AND DISCUSSION}

\subsection{Depth and Width Computation}

The calculated flow areas for rain and dry season are show in Table 1 and Table 2 respectively. The flow area across River Osun in dry season ranges between $3.83-19.2 \mathrm{~m}^{2}$ while it ranges between 13.5 and $47.5 \mathrm{~m}^{2}$. The highest flow area in dry season was recorded at upstream while the lowest was recorded at midstream. Also, the highest flow area in rain season was recorded at midstream while the lowest was recorded at downstream.

It was observed from the land using the Map at Figure 6 that farming activities and presence of forest at $T_{1}$ are the factors responsible for the highest measured SSC at sampling station $T_{1}$. Also the presence of little forest and woodland at sampling station $T_{4}$ as shown in Figure 6 is the factor responsible for the higher measure suspended sediment concentration at $T_{4}$. Sampling station $T_{2}$ and $T_{3}$ are within urban area as shown in figure 6 of. The presence of road and drainage in urban area enhance movement of surface run off directly into the river. Hence, the highest discharge recorded at $T_{2}$ and $T_{3}$ during rainy season could be attributed to the high influx of surface run off entering directly to the water body. 
Advances In Multidisciplinary

Aivis \& Scientifie Research

Table 1: Rain Season Cross-sectional Flow Area Computation at Sampling Stations

\begin{tabular}{lcccc}
\hline Station & $\mathbf{T}_{\mathbf{1}}$ & $\mathbf{T}_{\mathbf{2}}$ & $\mathbf{T}_{\mathbf{3}}$ & $\mathbf{T}_{\mathbf{4}}$ \\
\hline Area $\left(\mathbf{c m}^{\mathbf{2}}\right)$ & 192,000 & 38,340 & 46,865 & 75,000 \\
\hline
\end{tabular}

Table 2: Dry Season Cross-sectional Flow Area Sampling Stations Computation

\begin{tabular}{llrrr}
\hline Station & $\mathbf{T}_{1}$ & \multicolumn{1}{c}{$\mathbf{T}_{\mathbf{2}}$} & \multicolumn{1}{c}{$\mathbf{T}_{3}$} & $\mathbf{T}_{\mathbf{4}}$ \\
\hline Area $\left(\mathbf{c m}^{\mathbf{2}}\right)$ & 453,040 & 474,640 & 249,360 & 135,120
\end{tabular}

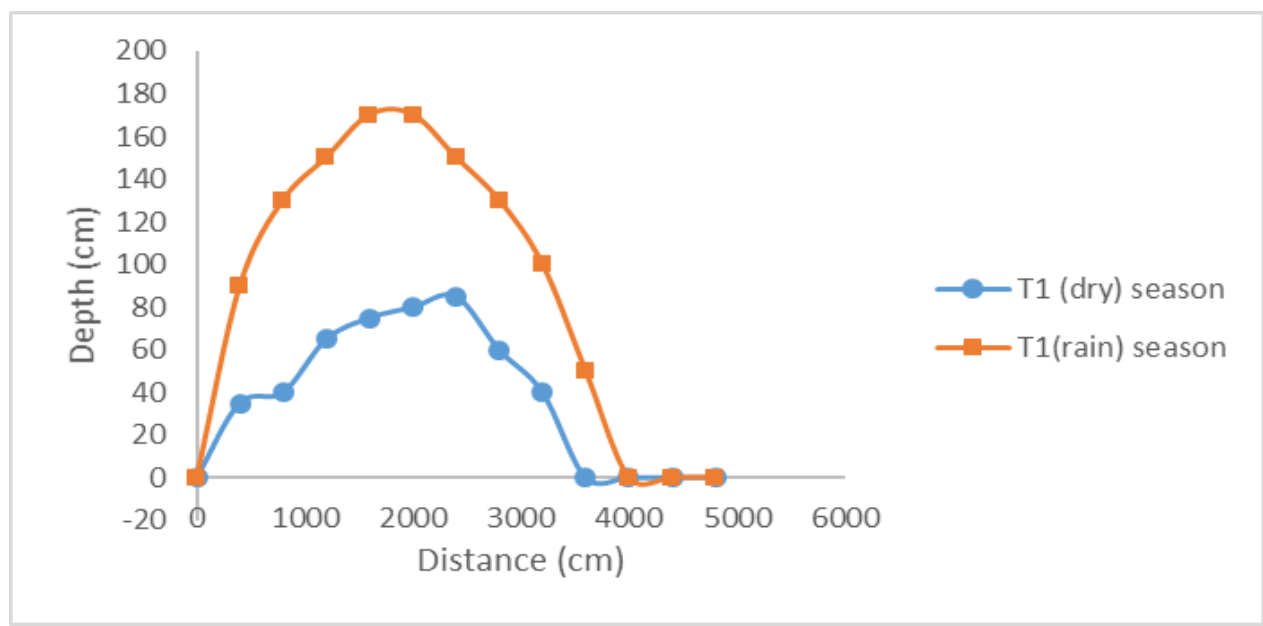

Figure 2: Slice through River Osun at $\mathrm{T}_{1}$ for Dry and Rain Season

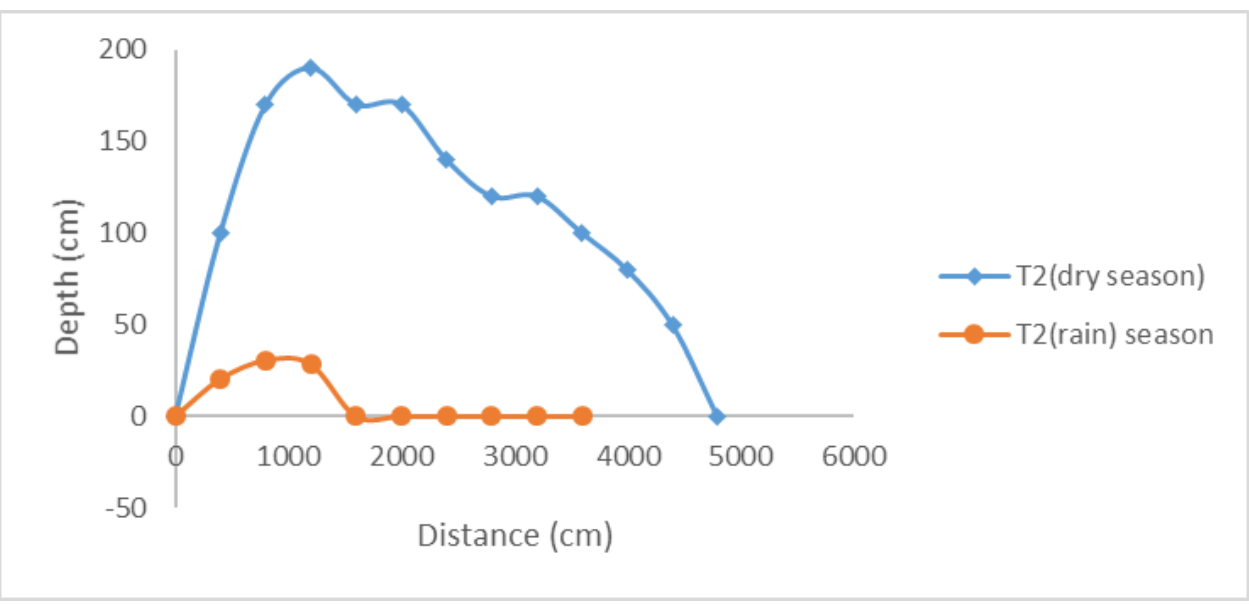

Figure 3: Slice through River Osun at $\mathrm{T}_{2}$ for Dry and Rain Season 


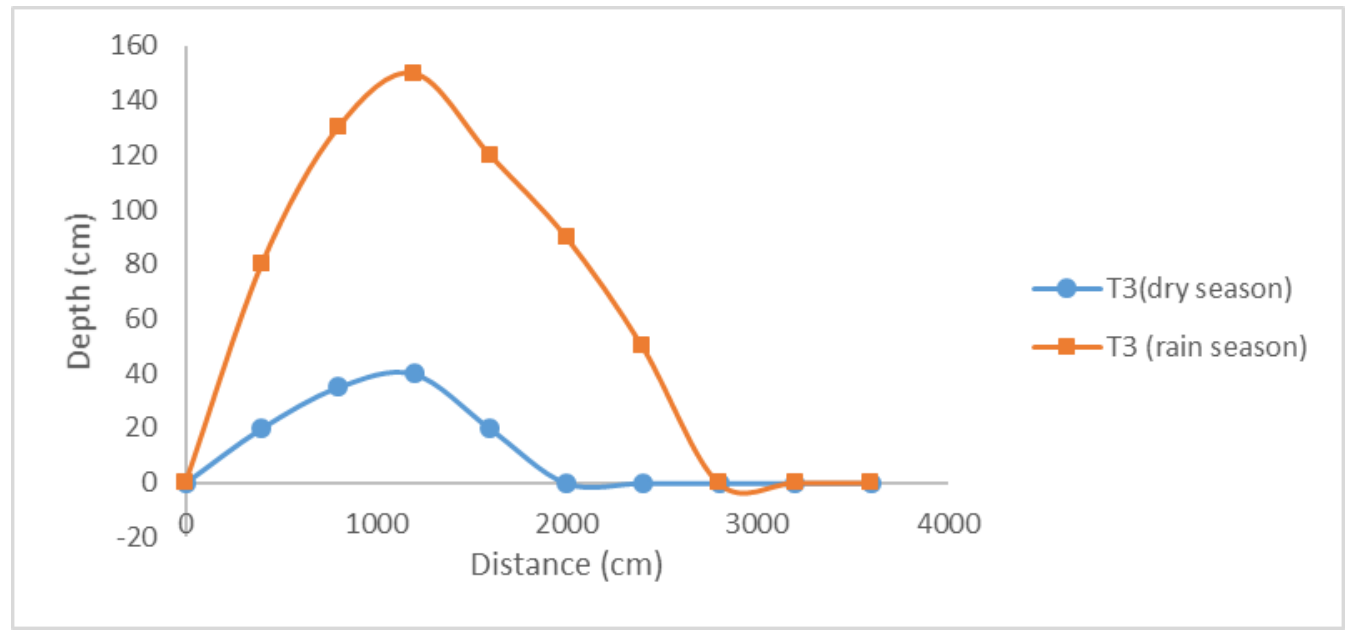

Figure 4: Slice through River Osun at $\mathrm{T}_{3}$ for Dry and Rain Season

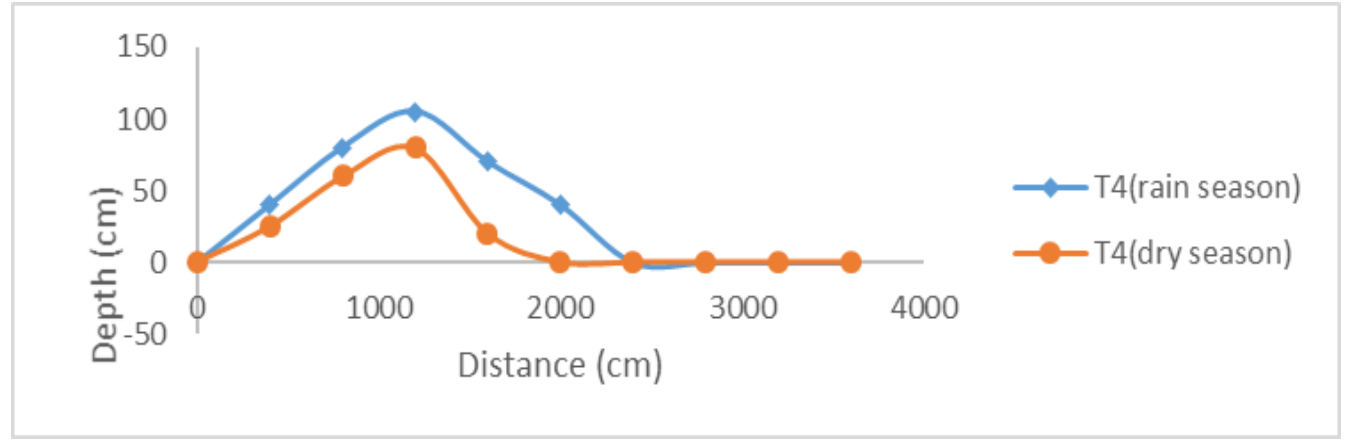

Figure 5: Slice through River Osun at $\mathrm{T}_{4}$ for Dry and Rain Season

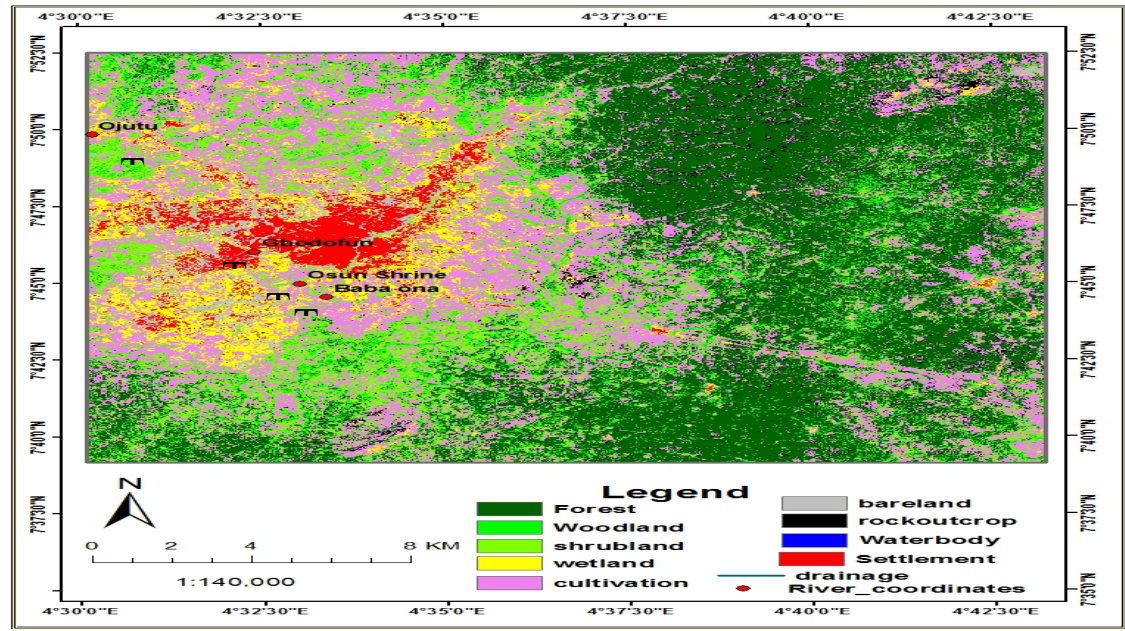

Figure 6: River Osun Land use Map 


\subsection{Wetted Perimeter}

The wetted perimeter is relatively low in midstream at dry season; its average at midstream is $0.113 \mathrm{~m}$ while the highest value was recorded at the upstream. It's important to note that the difference between wetted perimeter obtained in dry season and rain season at both upstream and downstream is relatively low compare to the difference between the wetted perimeters obtained in midstream. Table 3 and Table 4 show the respective wetted perimeter in dry and rain season.

Table 3: Wetted Perimeter at Dry Season

\begin{tabular}{|c|c|c|c|c|}
\hline \multirow[t]{2}{*}{ Distance $(\mathbf{c m})$} & \multicolumn{4}{|c|}{ Wetted Perimeter (cm) } \\
\hline & $\mathrm{T}_{1}$ & $\mathrm{~T}_{2}$ & $\mathrm{~T}_{3}$ & $\mathrm{~T}_{4}$ \\
\hline 0 & 0 & 0 & 0 & 0 \\
\hline 400 & 401.53 & 400.50 & 400.50 & 400.78 \\
\hline 800 & 400.03 & 400.12 & 400.28 & 401.53 \\
\hline 1200 & 400.78 & 400.00 & 400.04 & 400.50 \\
\hline 1600 & 400.12 & 400.98 & 400.50 & 404.47 \\
\hline 2000 & 400.03 & 0 & 0 & 0 \\
\hline 2400 & 400.78 & 0 & 0 & 0 \\
\hline 2800 & 400.78 & 0 & 0 & 0 \\
\hline 3200 & 400.50 & 0 & 0 & 0 \\
\hline 3600 & 402.00 & 0 & 0 & 0 \\
\hline & 3605.80 & 1601.60 & 2001.82 & 2007.78 \\
\hline
\end{tabular}

Table 4: Wetted Perimeter at Rainy Season

\begin{tabular}{lllll}
\hline Distance (cm) & \multicolumn{3}{c}{ Wetted Perimeter $(\mathbf{c m})$} & $\mathrm{T}_{4}$ \\
\hline 0 & $\mathrm{~T}_{1}$ & $\mathrm{~T}_{2}$ & $\mathrm{~T}_{3}$ & 402.00 \\
400 & 0 & 0 & 407.92 & 402.00 \\
800 & 410.00 & 412.31 & 403.11 & 400.78 \\
1200 & 402.00 & 405.25 & 400.50 & 401.53 \\
1600 & 400.50 & 400.50 & 401.12 & 401.12 \\
2000 & 400.50 & 400.50 & 401.12 & 402.00 \\
2400 & 400.00 & 400.00 & 402.00 & 0 \\
2800 & 400.50 & 401.12 & 403.11 & 0 \\
3200 & 400.50 & 400.50 & 0 & 0 \\
3600 & 401.12 & 400.00 & 0 & 0 \\
4000 & 403.11 & 400.50 & 0 & 0 \\
4400 & 403.11 & 400.50 & 0 & 0 \\
4800 & 0 & 401.12 & 0 & 0 \\
$\Sigma$ & 0 & 403.11 & 0 & 2409.43 \\
\hline
\end{tabular}

\subsection{Rating Curve Analysis}

The rating curve data is presented in Table 5.The correlation was acceptable because $r$ fall within 0.6-1, therefore rating equation in equation 7 was developed

$$
Q=0.467(G-0.368) .749
$$

This rating equation in was calibrated by comparing it with the measured discharged across River Osun. Table 6 shows the stage and discharge data used in developing the rating equation across the river. The rating curve develop was used to estimate discharge between February 2016 to July 2016. 
Table 5: Rating Curve Data

\begin{tabular}{lllllllll}
\hline \multicolumn{1}{c}{$\mathbf{G}$} & \multicolumn{1}{c}{$\mathbf{Q}$} & $\mathbf{A}$ & $\mathbf{G}-\mathbf{a}$ & $\mathbf{X}=\mathbf{l o g}(\mathbf{G}-\mathbf{a})$ & $\mathbf{y}=\log \mathbf{Q}$ & $\mathbf{X Y}$ & $\mathbf{X}^{*} \mathbf{X}$ & $\mathbf{Y}^{*} \mathbf{Y}$ \\
\hline 1 & 2.056 & 0.368 & 0.632 & -0.19928 & 0.313023 & -0.06238 & 0.039714 & 0.097983 \\
1.2 & 3.03 & 0.368 & 0.832 & -0.07988 & 0.481443 & -0.03846 & 0.00638 & 0.231787 \\
1.7 & 7.7 & 0.368 & 1.332 & 0.124504 & 0.886491 & 0.110372 & 0.015501 & 0.785866 \\
0.55 & 1.22 & 0.368 & 0.182 & -0.73993 & 0.08636 & -0.0639 & 0.547494 & 0.007458 \\
0.5 & 0.96 & 0.368 & 0.132 & -0.87943 & -0.01773 & 0.015591 & 0.77339 & 0.000314 \\
0.4 & 0.309 & 0.368 & 0.032 & -1.49485 & -0.51004 & 0.762436 & 2.234577 & 0.260142 \\
0.7 & 0.98 & 0.368 & 0.332 & -0.47886 & -0.00877 & 0.004201 & 0.229309 & $7.7 \mathrm{E}-05$ \\
1.05 & 1.92 & 0.368 & 0.682 & -0.16622 & 0.283301 & -0.04709 & 0.027628 & 0.08026 \\
1 & 2.065 & 0.368 & 0.632 & -0.19928 & 0.31492 & -0.06276 & 0.039714 & 0.099175 \\
0.6 & 0.76 & 0.368 & 0.232 & -0.63451 & -0.11919 & 0.075625 & 0.402605 & 0.014205 \\
0.7 & 0.451 & 0.368 & 0.332 & -0.47886 & -0.34582 & 0.165602 & 0.229309 & 0.119594 \\
0.55 & 0.597 & 0.368 & 0.182 & -0.73993 & -0.22403 & 0.165763 & 0.547494 & 0.050188 \\
\hline
\end{tabular}

Table 6: Comparison of measured and simulated discharge on River Osun

\begin{tabular}{|c|c|c|c|c|c|}
\hline Sampling Station & $\begin{array}{l}\text { Measured discharge } \\
\left(\mathrm{m}^{3} / \mathrm{s}\right)\end{array}$ & $\begin{array}{l}\text { Simulated } \\
\left(\mathrm{m}^{3} / \mathrm{s}\right)\end{array}$ & Discharge & $\begin{array}{l}\text { Percentage } \\
(\%)\end{array}$ & Variation \\
\hline \multirow[t]{2}{*}{$\mathrm{T}_{1}$} & 1.64 & 1.73 & & +5.2 & \\
\hline & 3.00 & 4.50 & & +33.0 & \\
\hline \multirow[t]{2}{*}{$\mathrm{T}_{2}$} & 1.35 & 0.69 & & -44.0 & \\
\hline & 4.10 & 11.87 & & +65.0 & \\
\hline \multirow[t]{2}{*}{$\mathrm{T}_{3}$} & 1.50 & 1.03 & & -31.0 & \\
\hline & 3.90 & 15.71 & & +75.0 & \\
\hline \multirow[t]{2}{*}{$\mathrm{T}_{4}$} & 1.64 & 1.62 & & -1.2 & \\
\hline & 1.68 & 1.76 & & +4.5 & \\
\hline
\end{tabular}




\section{CONCLUSION AND RECOMMENDATION}

\subsection{Conclusion}

Based on the findings from this study, the following conclusions can be drawn; the discharge and cross sectional area across River Osun ranges between $(0.53-17.46) \mathrm{m}^{3} / \mathrm{s}$ and $(3.83-47.46) \mathrm{m}^{2}$. The slope and depth across river Osun range from $(0.0032-0.0046)$ and $(0.2-1.9) \mathrm{m}$. The developed rating curve on River Osun was $\mathrm{Q}=0.467(\mathrm{G}-0.368)^{0.749}$. The seasonal bed load across the river is $95.22 \%$ of the measured load which gives $2358.77 \times 10^{3}(\mathrm{~kg} /$ year)

\subsection{Recommendation}

Routine maintenance of waterways in Nigeria in other to provide easy access of researchers in taking field measurement for morphological studies.

\section{Acknowledgement}

The authors acknowledge Tertiary Education Trust Fund TETFund and Authorities of Ladoke Akintola University of Technology, Ogbomoso for the Institution Based Research (IBR) grant (PV No: 00082805) to carry out this research. 


\section{REFERENCES}

1. Adegbola, A.A. and Olaniyan O.S. (2012). Temporal variation of Sediment Transport in RiverOmi, South-Western Nigeria. International Journal of Applied Engineering Research 4(7), 421431.

2. Adegbola, A.A. and Olaniyan, O.S. (2012). Estimation of Bed Load Transport in River Omi, South-Western Nigeria using Grain Size Distribution Data. International Journal of Engineering and Technology 2(9), 1587-1592.

3. Adeogun, B.K., Igboro, S.B. and Ibrahim, F.B. (2011). Estimate of Bed Load Transport in Kubani Watershed in Northern Nigeria using Grain Size Distribution Data, International Journal of Water Resources and Environmental Engineering 3(5), 102-107.

4. Ahrens J.P. (2000). The Fall Velocity Equation, Journal of Waterway, Port, Coastal, Ocean Engineering.126 (2)

5. Bagnold, R.A. (1996). An Approach to Sediment Transport Problem from General Physics Geological Survey Professional Paper, United State Government Printing Office Washington.

6. Bishaw, D. and Kedir, Y. (2015). Determining sediment load of Awash Tiver Meteharra Sugarcane Irrigation Scheme in Ethiopia, Journal of Environment and Earth Science, 5(13),110117.

7. Brown Cunningham Gannuch, C.R. (2004). Report on the feasibility of a small-scale physical modeof the lower Missippi River Delta for testing water and sediment diversion project, Louisiana State University.

8. Crest (2006). On Reintroduction Riverine Process in the Mississippi Delta Region", http://www.gulfcrest.org/docs/diversion.

9. Hickin, E.J. (1995). River Geomorphological, International Association of Geomorphologists, Wiley, United State of California.

10. Huber Chanson (1999). The Hydraulic Open Channel Flow, Arnold, 338 Euston Road, London NW1 3BH, UK.

11. James, P. S., David, C.B. and Jens, M. S. (1986). Fluvial - Deltaic Environment, springer Verlag. New York, Berlin.

12. Kalin, L. and Hantush, M.M. (2003). Evaluation of Sediment Transport Models and Comparative Application of two Watershed Models, National Risk Management Research Laboratory, Office of Research and Development US Environmental Protection Agency, Cincinnatus, Ohi O 4526.

13. Karim, M.F. And Kennedy J.F. (1990). "Menu of Coupled Velocity and Sediment Discharge Relations for Rivers.Journals of Hydraulic Engineering, ASCE 116(8), 978-996.

14. Kiat, C.H., Ghani, A.A. and Wen, L.M. (2007). Development of Modified Einstein Bed load Equation for Sandy stream in Malaysia, " $2^{\text {nd }}$ International Conference on Managing Rivers in the $21^{\text {st }}$ Century". Riverside Kuching, Sarawak, Malasia. 533-538.

15. Knight D. (1998). Fluvial and processes, a new perspective No. Ed, 2 Arnold, Headline, Plc.

16. Mashriqui, H.S. (2003). Hydrodynamic and Sediment Transport Modelling of Deltaic Sediment Process. Dissertation of Department of Civil and Environmental Engineering, Graduate Faculty of the State University and Agriculture and Mechanical College, Louisiana|.

17. Meyer -Peter, E., and Muller, R. (1948). Formula for Bed Load Transport, Proceeding of 2nd meeting of the IAHR, Stockholm, $39-64$.

18. Molinas, A. and Wu, B. (2001) Transport Sediment in Large Sand-Bed Rivers, Journal of Hydraulics Research, 39(2): 138-145.

19. Olaniyan O.S. (2014). Numerical Modeling of Sediment Transport in River Omi, South-Western Nigeria. PhD Thesis Submitted to Civil Engineering Department, Ladoke Akintola University of Technology, Ogbomoso, Nigeria. 